\title{
KAJIAN VARIASI PENGOLAHAN TEH DAUN SIRSAK, SIFAT FISIK, ORGANOLEPTIK DAN KADAR VITAMIN E
}

\author{
Saila Maharani*, Idi Setyobroto, Joko Susilo \\ Jurusan Gizi Poltekkes Kemenkes Yogyakarta \\ *Email : saila_maharani@yahoo.com
}

\begin{abstract}
Soursop leaf tea is a beverage product that has a high antioxidant consistency, so that many benefits are obtained when taking it. It can be a healthy alternative beverage by knowing the best processing method and the content of soursop leaves. Soursop leaf contains vitamin E of $12.05 \mathrm{~g} / 100 \mathrm{gr}$, it also has other steroid / terpenoids, flavonoids, coumarin, alkaloids and tannins. Flafonoid has functions as antioxidant for cancer, anti-microbial, anti-virus regulator of photosynthesis and plant growth regulator. The highest nutrient the soursop leaf is vitamin E so it is beneficial for health. The purpose of this study is to determine the best processing method and know the content of soursop leaf tea processing and this study aims to determine the different variation in processing soursop leaf tea reviewed from the physical characteristic, the organoleptic characteristic and vitamin E of the product.

This type of research was Random Simple (US) using two treatments, each treatment was done with twice repetition and three times of the experiment so it had 18x experimental unit. The data of the physical characteristic were analyzed descriptively and the organoleptic characteristic data were analyzed with the Kruskal-Wallis test while the data of vitamin $E$ level were analyzed descriptively. The results of the physical characteristics showed that tea has dark brown color, distinctive aroma of soursop leaves and a very bitter taste. The organoleptic characteristic resulted the most preferred color was from brewed soursop leaf tea, the best taste was from boiled soursop leaf tea and the most preferred aroma was from boiling process. The highest level of vitamin $E$ was tea powder that had not been processed into drinks. The conclusion from this study is the best variation of soursop leaf tea processing on the physical properties (color, aroma, flavor) organoleptic properties (color, aroma, flavor) and vitamin $E$ is the boiling process.
\end{abstract}

Keywords: $\quad$ Soursop Leaf Tea, Physical Characteristics, Organoleptic Characteristics, Vitamin E

\section{ABSTRAK}

Minuman teh daun sirsak adalah produk minuman yang memiliki konsentrasi antioksidan yang tinggi, sehingga banyak manfaat yang didapatkan ketika mengkonsumsinya. Bisa menjadi alternative minuman yang menyehatkan dan mengetahui pengolahan yang paling baik untuk pengolahannya dan kandungan daun sirsak.. Daun sirsak mengandung vitamin $\mathrm{E}$ sebesar 12,05 g/100gr, kandungan senyawa dalam daun sirsak antara lain steroid/terpenoid, flavonoid, kumarin, alkaloid dan tanin. Senyawa flafonoid mempunyai fungsi sebagai anti oksidan untuk penyakit kanker, anti mikroba, anti virus pengatur fotosintesis dan pengatur tumbuh. Kandungan zat gizi paling tinggi pada daun sirsak adalah vitamin $E$ sehingga bermanfaat untuk kesehatan. Penelitian ini bertujuan untuk mengetahui pengolahan yang paling baik dan mengetahui kandungan yang terdapat pada pengolahan teh daun sirsak dan penelitian ini bertujuan untuk mengetahui perbedaan variasi pengolahan teh daun sirsak pada produk terhadap sifat fisik, sifat organoleptik dan kadar vitamin E. Jenis penelitian ini adalah Acak Sederhana (AS) dengan menggunakan dua perlakuan, masing-masing perlakuan dilakukan dua kali ulangan dan tiga kali unit percobaan sehingga mendapatkan 18x unit percobaan. Pengolahan dan analisis data sifat fisik secara deskriptif dan sifat organoleptik dengan Kruskal-Wallis, sedangkan uji kadar vitamin E dianalisis dengan uji deskriptif. Hasil sifat fisik teh bewarna coklat tua, aroma khas daun sirsak dan rasa sangat pahit. Sifat organoleptik warna yang paling disukai adlah teh daun sirsak dengan pengolahan penyeduhan, rasa adalah teh daun sirsak dengan pengolahan perebusan dan aroma adalah pengolahan perebusan. Kadar vitamin E paling tinggi adalah serbuk teh yang belum diolah menjadi minuman. Kesimpulan dari penelitian ini adalah variasi pengolahan teh daun sirsak terbaik terhadap sifat fisik (warna, aroma, rasa) sifat organoleptik (warna, aroma, rasa) dan kadar vitamin E adalah pengolahan seduh.

Kata Kunci : Teh Daun Sirsak, Sifat Fisik, Sifat Otganoleptik, Vitamin E

\section{PENDAHULUAN}

Tanaman sirsak (Anona muricata Lin.) berasal dari bahasa Belanda, yakni zurzak berarti kantong asam. Daun sirsak banyak digunakan sebagai obat herbal untuk mengobati berbagai penyakit, antara lain : penyakit asma di Andes Peru, diabetes dan kejang di
Amozania Peru'. Kandungan senyawa dalam daun sirsak antara lain steroid/terpenoid, flavonoid, kumarin, alkaloid, dan tanin. Senyawa flavonoid berfungsi sebagai antioksidan untuk penyakit kanker, anti mikroba, anti virus, pengatur fotosintetis, dan pengatur tumbuh². 
Daun sirsak mengandung vitamin E sebesar 12,05 g/100gr, kandungan senyawa dalam daun sirsak antara lain steroid/terpenoid, flavonoid, kumarin, alkaloid, dan tanin. Senyawa flavonoid mempunyai fungsi sebagai antioksidan untuk penyakit kanker, anti mikroba, anti virus, pengatur fotosintetis, dan pengatur tumbuh $\mathrm{h}^{2,3}$.

Teh adalah minuman yang paling banyak dikonsumsi di Indonesia. Diwarung maupun rumah makan manapun, minuman ini selalu jadi favorit konsumen, baik dalam bentuk dingin maupun panas. Faktanya tingkat konsumsi masyarakat indonesia terhadap teh masih ada di peringkat 70 dunia. Ini dikatakan oleh pakar teh indonesia, Ratna Soemantri. Peringkat itu memang tidak menggambarkan bahwa masyarakat indonesia tidak menyukai teh. Tapi angka itu menunjukkan berapa besar teh yang dikonsumsi oleh orang dewasa Indonesia.

Kesehatan kini masih menjadi masalah penting bagi manusi di seluruh dunia. Lebih dari satu milyar manusia di dunia memiliki resiko yang sangat berbahaya dikarenakan salah memilih obat demi tubuhnya. Selain menimbulkan masalah kesehatan obat-obatan yang mengandung bahaya kimia kini sudah merenggut banak nyawa. Hal ini disebabkan oleh pemakaian yang cukup sering dan berdampak jangka panjang dan cacat tubuh yang sukar untuk disembuhkan.

Masyarakat Indonesia menggunakan daun sirsak sebagai obat herbal untuk mengobat penyakit kanker, yaitu dengan cara meminum air rebusan daun sirsak segar. Air rebusan daun sirsak segar dapat menimbulkan efek panas seperti pada kemoterapi, namun air rebusan daun sirsak ini hanya membunuh sel-sel yang abnormal (kanker) dan membiarkan selsel normal tetap tumbuh. Hal ini berbeda dengan efek yang ditmbulkan pada pengobatan kemoterapi, dimana pengobatan kemoterapi ini tidak saja membunuh sel-sel abnormal (kanker) tetapi sel-sel yang normalpun ikut mati ${ }^{4}$.

Air rebusan daun sirsak segar telah lama digunakan sebagai obat herbal untuk penyakit kanker, namun bentuk teh daun sirsak belum banyak digunakan oleh masyarakat. Karena itu perlu dilakukan kajian tentang analisis antioksidan dalam teh daun sirsak, untuk mengali potensi daun sirsak sebagai minuman fungsional yang dapat difungsikan antara lain sebagai obat herbal.

Vitamin E merupakan vitamin yang larut dalam lemak, terdiri dari campuran tokoferol (a, b, g, dan d) dan tokotrienol (a, b, g, dan d). Pada manusia atokoferol merupakan vitamin $\mathrm{E}$ yang paling penting untuk aktifitas biologi tubuh ${ }^{5}$. Daun sirsak dengan kadar kandungan vitamin $\mathrm{E}$ dapat menangkal radikal bebas selain itu juga dapat mempercepat penyembuhan penyakit, mencegah terjadinya penyebab luka, menjaga kesehatan sel darah merah dan syaraf serta melindungi membran sel.

Penelitian pada produk tanaman yang memiliki kandungan vitamin E yang tinggi menunjukan bahwa tanaman ini dapat memberikan alternatif minuman herbal yang bersifat murah. Salah satunya adalah tanaman sirsak (Annona muricata). Sirsak adalah tanaman yang daunnya mengandung flavanoid ${ }^{6}$. Flavanoid adalah senyawa yang terkandung dalam tumbuhan dan dapat digunakan sebagai alternatif lain untuk pengobatan.

Tuminah melaporkan bahwa ekstrak yang terkandung pada daun sirsak (Annona muricata) memiliki kandungan vitamin $\mathrm{E}$ dengan kandungan $45,9 \%^{7}$. Penelitian Daun teh dilayukan pada $70^{\circ} \mathrm{C}$ selama 4 menit. Kondisi operasi pelayuan ini diacu sebagai kondisi optimum pelayuan daun sirsak pada penelitan ini. Sedangkan Proses pengeringan daun sirsak dari hasil experimen dilakukan dengan 2 cara yaitu dengan bantuan sinar matahari dan oven, dengan waktu yang masing-masing sama. Hal ini dapat diperhatikan bahwa adanya ketidak samaan dalam proses pelayuan yang dilakukan. Uji yang dilakukan pada produk teh daun sirsak yang dihasilkan meliputi: uji sifat fisik, uji sifat organoleptik, kadar vitamin $\mathrm{E}$.

Minuman teh daun sirsak adalah produk minuman yang memiliki konsistensi antioksidan yang tinggi, sehingga banyak manfaat yang didapatkan ketika mengkonsumsinya. Tujuan penelitian ini adalah untuk mempelajari adanya perbedaan hasil yang di dapatkan setelah mengolah daun sirsak dengan dua cara yaitu perebusan dan penyeduhan menjadi teh daun sirsak.

Produksi teh di Indonesia berada pada urutan nomor 5 didunia. Meski berada pada urutan tersebut, namun konsumsi teh di Indonesia masih tergolong rendah. Teh yang banyak dan sering dikonsumsi masyarakat di Indonesia adalah teh hitam dan teh melati yang daya jualnya sangat tinggi dan kandungan gizi pada daun tersebut belum memenuhi syarat sehat masyarakat indonesia. Oleh karena itu akan dilakukan penelitian tentang variasi pengolahan teh daun sirsak ditinjau dari uji kadar sifat fisik organoleptik dan kadar vitamin $\mathrm{E}$ yang akan dibandingkan pengolahan mana yang baik dalam proses pembuatan teh daun sirsak.

\section{METODE}

Jenis penelitian ini merupakan penelitian eksperimental semu yang dilakukan dengan 2 perlakuan, 2 ulangan dan 3 unit percobaan sehingga terdapat 18 unit percobaan. Produk dari penelitian ini kemudian diamati dan diukur sifat fisik, organoleptik dan kadar vitamin $\mathrm{E}$.

Penelitian ini dilaksanakan pada bulan Juni 2015 di Laboratorium IImu Bahan Makanan Jurusan Gizi 
Poltekkes Kemenkes Yogyakarta meliputi pengujian sifat fisik dan pengujian sifat organoleptik. Pengujian kadar vitamin $\mathrm{E}$ teh dilakukan di Laboratorium ChemMix Pratama, Banguntapan Bantul. Bahan yang digunakan dalam penelitian ini antara lain : Daun sirsak dan air mengalir. Cara pembuatan teh yaitu :

1. Persiapan pembuatan teh

Daun teh yang digunakan adalah daun sirsak yang bermutu baik dan masih beraroma daun sirsak. Bagian daun hijau yang baik digunakan untuk membuat teh adalah urutan ke 4 dari pucuk daun. Dalam pemilihan daun sirsak memilih daun yang bersih dari kotoran yang ada dan tidak ada goresan di permukaan daun. Pencucian daun sirsak membersihkan kotoran-kotoran yang masih tertinggal. Pengeringan bertujuan untuk menghilangkan jumlah kadar air yang terkandung pada daun sirsak. Penggilingan merupakan proses untuk mendapatkan bubuk teh. Pengayakan dilakukan dengan 200 mesh sehingga diperoleh teh yang sedikit halus.

2. Pengolahan Teh Daun Sirsak

Langkah-langkah pengolahan teh daun sirsak adalah sebagai berikut Seleksi daun sirsak, pilih daun sirsak yang tidak terlalu tua atau muda, pilih daun yang memiliki bentuk sempurna tanpa ada bekas gigitan ulat, lalu Cuci daun sirsak dengan air bersih agar kotoran yang menempel seperti tanah atau debu dapat hilang, selanjutnya, Tiriskan daun sirsak yang telah dicuci agar sisa air dari pencucian hilang, Setelah sisa air hilang, rajang atau potongpotong daun sirsak menjadi kecil-kecil. Hal ini bertujuan agar kandungan pada daun sirsak dapat keluar dengan mudah pada saat diseduh, dan membantu proses pengeringan agar lebih cepat, Keringkan daun sirsak yang telah dirajang dengan cara dijemur pada matahari selama 3-4 jam sampai kandungan air tidak lebih dari 8 persen, Pastikan membolak-balik daun selama proses penjemuran agar daun kering secara merata. Bila ingin menggunakan oven, gunakan suhu 60 derajat Celcius selama 30 menit, Teh daun sirsak telah siap untuk dikemas dan dikonsumsi.

Pengujian sifat fisik meliputi warna, aroma, rasa. Pengujian organoleptik menggunakan panelis agak terlatih dengan metode hedonic scale test. Pengujian kadar vitamin E menggunakan metode titrasi. Hasil uji sifat fisik dianalisis secara deskriptif. Hasil uji organoleptik dianalisis menggunakan uji Kruskall Wallis, jika ada perbedaan dilanjutkan dengan uji Mann Whitney. Hasil uji kadar vitamin E dianalisis secara deskriptif.

\section{HASIL DAN PEMBAHASAN}

Sifat fisik teh adalah karakteristik teh daun sirsak secara fisik, yang meliputi warna, aroma, rasa.

Warna, aroma, rasa dinilai secara subyektif. Hasil sifat fisik teh daun sirsak dapat dilihat pada Tabel 1

Tabel 1. Sifat Fisik Serbuk Teh Daun Sirsak

\begin{tabular}{cc}
\hline Sifat fisik & Hasil \\
\hline Warna & Hijau Tua \\
Aroma & Khas Daun Sirsak \\
Rasa & Sangat Pahit \\
\hline
\end{tabular}

Tabel 2. Sifat Fisik Pengolahan Teh Daun Sirsak

\begin{tabular}{cccc}
\hline Pengolahan Teh & Warna & Aroma & Rasa \\
\hline Rebus & Coklat Tua & Khas daun sirsak & Pahit +++ \\
Seduh & Coklat Muda & Khas daun sirsak & Pahit + \\
\hline
\end{tabular}

Tabel diatas menunjukkan hasil pengamatan terhadap warna Serbuk teh memiliki aroma yang khas dan bewarna hijau tua karena berbahan dasar daun sirsak. Warna serbuk teh daun sirsak yaitu hijau tua disebabkan karena pada daun sirsak terdapat klorofil yang memberi khas warna hijau, sehingga setelah daun sirsak dihaluskan akan tetap menghasilkan warna hijau tua. Hal ini dikarenakan juga pada proses pembuatan serbuk teh harus ada proses pengeringan sehingga pada waktu penghalusanpun teh juga menghasilkan warna hijau tua, semakin banyak daun sirsak yang diolah semakin pekat warnanya. Seperti halnya Lenny (2006) yang menggunakan daun sirsak sebagai bahan dasar pembuatan teh semakin banyak daun sirsak yang diolah warnanya akan semakin hijau'.

Aroma berasal dari molekul-molekul yang menguap dari teh daun sirsak yang ditangkap oleh hidung sebagai indera pembau. Aroma teh daun sirsak antar variasi pengolahan sama. Semua variasi pengolahan menunjukan aroma khas daun sirsak. Hal ini dikarenakan bahan dasar pembuatan sudah disortir dengan kualitas yang bagus. Selain itu, aroma dedaunan merupakan sifat khas daun sirsak dan teh yang dihasilkan juga masih baru belum melalui masa penyimpanan. Aroma khas daun sirsak dikatakan normal dan dapat diterima oleh indera pembau. Hal ini sesuai dengan syarat mutu teh menurut SNI 03-38362012 (Badan Stadarisasi Nasional, 2012) bahwa syarat mutu teh uji aroma dengan persyaratan normal atau dapat diterima.

Rasa adalah karakteristik diamati dengan panca indera pengecap secara subyektif oleh peneliti. Rasa teh daun sirsak antar variasi pengolahan berbeda. Semakin tinggi suhu pengolahan semakin pahit rasa yang dihasilkan. Adanya rasa pahit ini disebabkan oleh kandungan daun sirsak yang memiliki senyawa alkaloid $2,9 \mathrm{mg}^{8}$. Berdasarkan penelitian sebelumnya 
yang dilakukan oleh Idesanti menunjukkan bahwa semakin banyak daun sirsak yang diolah maka menghasilkan rasa yang semakin pahit ${ }^{6}$.

Hasil uji organoleptik dengan variasi pengolahan teh daun sirsak meliputi warna, aroma, rasa. Hasil uji statistik menunjukkan bahwa warna dan aroma memiliki perbedaan bermakna $(p<0,050)$, kemudian dilanjutkan menggunakan uji statistik Mann-Whitney untuk mengetahui adanya perbedaan antara dua variasi perlakuan. Hasil uji organoleptik sosis dengan uji statistik dapat dilihat pada Tabel 2.

Tabel 2. Uji Kruskall Wallis Sifat Organoleptik Teh Daun Sirsak

\begin{tabular}{cccc}
\hline \multirow{2}{*}{ Sifat Organoleptik } & \multicolumn{2}{c}{ Perlakuan } & P \\
\cline { 2 - 3 } & Rebus & Seduh & \\
\hline Warna & $17,90^{\mathrm{a}}$ & $33,10^{\mathrm{b}}$ & 0,000 \\
Aroma & $29,92^{\mathrm{a}}$ & $21,08^{\mathrm{b}}$ & 0,021 \\
Rasa & $28,00^{\mathrm{a}}$ & $23,00^{\mathrm{a}}$ & 0,196 \\
\hline
\end{tabular}

Keterangan : Notasi huruf yang berbeda $(a, b)$ pada baris yang sama menyatakan ada perbedaan yang nyata pada uji Mann-Whitney

Tabel 3. Kadar Vitamin E Variasi Pengolahan Teh Daun Sirsak

\begin{tabular}{cccc}
\hline \multirow{2}{*}{ Jenis Pengolahan } & \multicolumn{3}{c}{ Kadar Vitamin E (g\%) } \\
\cline { 2 - 4 } & Ulangan I & Ulangan II & Rata-rata \\
\hline Serbuk & 4,66 & 4,18 & 4,42 \\
Rebus & 0,67 & 0,67 & 0,67 \\
Seduh & 0,84 & 0,85 & 0,84 \\
\hline
\end{tabular}

Pengujian kadar vitamin E dilakukan dengan metode titrasi untuk mengetahui kadar vitamin $(\% \mathrm{~g})$ dalam teh daun sirsak. hasil yang diperoleh kemudian dianalisis secara deskriptif. Kadar vitamin $\mathrm{E}$ teh daun sirsak dengan variasi pengolahan seduh dan rebus dapat dilihat pada Tabel 3.

Pada hasil pengujian kadar vitamin E seperti terlihat pada tabel diatas memiliki perbedaan kadar vitamin E dari setiap perlakuan. Berdasarkan didapatkan hasil uji kadar vitamin E pengolahan teh daun sirsak serbuk, rebus dan seduh dapat diketahui bahwa vitamin $\mathrm{E}$ terbanyak pada serbuk teh yang belum di olah, hal ini disebabkan karena daun sirsak banyak mengandung vitamin E. Sedangkan pada pengolahan serbuk teh yang di seduh dan di rebus memiliki kandungan vitamin $\mathrm{E}$ yang lebih sedikit. Dari tabel 3 menunjukan bahwa pengolahan teh daun sirsak seduh memiliki kandungan lebih tinggi dari pada pengolahan teh daun sirsak yang direbus. Sehingga saat pengolahan teh dengan suhu yang lebih rendah tidak terlalu merusak vitamin yang ada didalam daun.

Teh daun sirsak dengan variasi pengolahan rebus dan seduh ini dapat dikonsumsi sebagai minuman yang memiliki kandungan vitamin E. Berdasarkan sifat fisik, organoleptik, dan kadar serat vitamin E yang dapat diterima adalah pengolahan teh seduh.

\section{KESIMPULAN}

Berdasarkan hasil penelitian dan pembahasan dapat ditarik kesimpulan sebagai berikut :

1. Ada perbedaan sifat fisik warna dan rasa pada teh daun sirsak pada variasi pengolahan rebus dan seduh yaitu semakin tinggi suhu pengolahan semakin bewarna coklat tua dan semakin pahit.

2. Tidak ada perbedaan sifat fisik aroma pada variasi pengolahan teh daun sirsak yaitu aroma samasama khas daun sirsak.

3. Ada perbedaan sifat organoleptik warna, aroma dan rasa pada variasi pengolahan rebus dan seduh yaitu warna paling disukai variasi pengolahan rebus, aroma paling disukai variasi pengolahan rebus, dan rasa paling disukai adalah variasi pengolahan rebus.

4. Ada perbedaan kadar vitamin E pada variasi pengolahan teh daun sirsak rebus dan seduh yang signifikan dengan uji deskriptif .

5. Berdasarkan analisa harga, uji fisik, uji organoleptik meliputi warna, aroma, rasa pada produk teh dapat diterima dan dapat dikembangkan

\section{SARAN}

1. Bagi peneliti selanjutnya dapat menemukan cara untuk menghilangkan rasa pahit yang ada pada produk teh daun sirsak variasi pengolahan rebus.

2. Bagi masyarakat yang ingin melakukan usaha teh daun sirsak dapat membudidayakan tanaman sirsak di sekitar rumah atau pekarangan karena disamping banyak khasiatnya juga memiliki vitamin $E$ yang cukup bagus dan murah.

\section{DAFTAR PUSTAKA}

1. Zuhud, E,. 2011. Bukti Kedahsyatan Sirsak Menumpas Kanker. Yunita Indah. Cet-1. Agromedia Pustaka : Jakarta.

2. Robinson, T. 1995. Kandungan Organik Tumbuhan 
Tinggi. Edisi ke-4 Terjemahan Kosasih Padmawinata. ITB Press. Bandung

3. Plantus. 2008. Biopestisida Sebagai Pengendali Hama dan Penyakit Tanaman Hias

4. Lenny S. 2006 . Senyawa Flavonoid, Fenilpropanoida dan Alkaloida. Medan : Fak. MIPA. USU.

5. Maria C Linder, 2006, Biokimia Nutrisi dan Metabolisme, Universitas Indonesia, Jakarta.
6. Idesanti. 1995. Telaah Senyawa Fenolik Daun Sirsak (Anona muricata Lin). Dept. Farmasi ITB: Bandung

7. Tuminah. (2013). Aktivitas Antioksidan dan Sifat Organoleptik Teh Daun Sirsak (Annona muricata Linn.) Berdasarkan Variasi Lama Pengeringan.Vol. 4, No. 7, pp.1-15

8. Indihastuti. 2007. Ekstrak Daun Sirsak. Jakarta : UI Press 